\title{
PROTOTYPE MONITORING SUHU BERBASIS MIKROKONTROLER PADA COOL BOX IKAN MENGGUNAKAN SENSOR DS18B20 DENGAN METODE FUZZY
}

\author{
Eka Setya Wijaya ${ }^{1}$, Muti ’a Maulida², Yuslena Sariं ${ }^{3}$, Andreyan Rizky Baskara4, \\ Akhmad Rivaldy ${ }^{5}$ \\ Program Studi Teknologi Informasi Universitas Lambung Mangkurat \\ JL. Brigjend H. Hasan Basry, Kayu Tangi, Banjarmasin, Kotak Pos 219 \\ ekasw@ulm.ac.id
}

\begin{abstract}
Often fish supply in to the consumers need long relatives distance and much time. Meanwhile the consumers always want fresh fish. The problem occurred was broken stock of fresh fish in every shipping and happened almost all the time. It made fish became stale and made supplier got lose. The study was took place in Batulicin Simpang Empat in a harbor (Pelelangan Pembongkaran Ikan) until now the handling of fish catches generally used ice block in the usual cool box. Using ice block is one of easiest method. Although, using ice block only could maintain low temperature in short time whereas the ideal temperature of cool box should be $10^{\circ}$ Celsius measured by usual temperature's device room. In shipping process, the driver unpack the cool box to checked temperaturemanually. This matter waste time and cost because the driver should provide extra ice block to maintain low temperature of cool box. In order to resolve the problem, monitoring could be done automatically by using a microcontroller chip in the cool box with DS18B20 censor and fuzzy methodbase microcontroller. The purpose was supplier could be helped to monitoring the stabilities of cool box temperature used website. This system is made by computerization. It would make supplier job easier because driver able to check fish condition without unpack the cool box and made time, energy and cost more efficient.
\end{abstract}

Keywords: Temperature Censor, Fish cool box microcontroller, Fuzzy method, and website

\begin{abstract}
Abstrak
Seringkali dalam penyuplaian ikan kepada konsumen membutuhkan jarak dan waktu yang relatif panjang, sedangkan konsumen selalu mengharapkan ikan segar. Permasalahan besar yang dihadapi dalam produksi ikan segar, yaitu persediaan yang rusak (broken stock) dalam jumlah yang banyak, sehingga jumlah ikan yang membusuk menjadi berlebihan dan akhirnya mengalami kerugian. Di Batulicin Simpang Empat, tempat dilakukanya penelitian, tepatnya di pelabuhan PPI (Pelelangan Pembongkaran Ikan), penanganan hasil tangkapan ikan saat ini masih menggunakan pendinginan es batu di dalam cool box biasa. Penggunaan es merupakan salah satu cara yang paling mudah dilakukan. Akan tetapi, pendinginan dengan menggunakan es batu hanya dapat mempertahankan suhu rendah dalam waktu yang singkat sedangkan suhu ideal dari dalam cool box adalah $10^{\circ} \mathrm{C}$ yang diukur dengan menggunakan alat suhu ruangan biasa. Jadi, saat perjalanan driver akan membongkar muatan dan mengecek apakah suhu turun atau tidak secara manual. Hal ini sangat memakan waktu dan biaya karena supplier selalu membawa cadangan es untuk berjaga-jaga jika suhu turun didalam cool box tersebut. Untuk mengatasi
\end{abstract}

Prototype Monitoring Suhu Pada Cool Box Ikan Dengan Metode Fuzzy (Eka Setya Wijaya)| 283 
permasalahan di atas, monitoring dapat dilakukan secara otomatis dengan memanfaatkan sebuah chip mikrokontroler pada cool box dengan sensor DS18B20 bersama metode fuzzy berbasis mikrokontroler. Tujuannya agar supplier dapat terbantu untuk memonitoring kestabilan suhu cool box dengan menggunakan website. Karena sistem dibuat terkomputerisasi maka akan memudahkan kinerja dari supplier atau driver sehingga driver dapat memonitor kondisi ikan di dalam cool box tanpa harus membongkar muatan dan hal ini dapan mengefisiensikan waktu, tenaga, dan biaya karena suhu cool box tetap terjaga dengan baik dan mudah.

Kata kunci: Sensor Suhu, Mikrokontroler Cool Box Ikan, Metode Fuzzy, dan website

\section{PENDAHULUAN}

Para supplier memegang peranan penting, agar ikan-ikan yang disuplai dalam kualitas yang baik. Permasalahan yang dihadapi dalam persediaan produk ikan segar, yaitu persediaan yang rusak (broken stock) sering kali berlebihan, sehingga banyak ikan yang membusuk dan mengalami kerugian. [1]

Penanganan hasil tangkapan ikan biasanya menggunakan pendinginan dengan es batu. Penggunaan es merupakan salah satu cara yang paling mudah dilakukan.

Proses penanganan ikan yang bertujuan untuk memperpanjang umur simpan ikan akan menambah biaya produksi pada ikan sehingga harga jual ikan akan naik. Biaya penyimpanan dan penanganan bahan dalam rantai pasok ikan terdapat disemua tahapan rantai pasok ikan mulai dari proses pengawetan sampai ke tangan konsumen. Biaya itu dibutuhkan untuk menjaga supaya ikan yang diterima konsumen tetap berkualitas baik, namun biaya tersebut merupakan sesuatu yang tidak diinginkan oleh supplier sehingga harus diminimalisir.

Salah satu kendala bagi supplier atau driver adalah pada saat perjalanan pengangkutan ikan melakukan monitoring kualitas suhu secara realtime. Para driver saat diperjalanan memeriksa suhu secara manual yaitu membuka box ikan tersebut satu persatu lalu mengecek suhu ikan dan itu sangat menghambat waktu, tenaga juga biaya. Untuk mengatasi permasalahan tersebut, monitoring dapat dilakukan secara otomatis dengan memanfaatkan sebuah chip mikrokontroler pada cool box dengan sensor.

Dan untuk memonitoring suhu yang dari penggunaan alat tersebut digunakan sebuah metode fuzzy digunakan untuk pengolahan data [8].

Pada penelitian ini akan dibuat sebuah prototype monitoring suhu menggunakan sensor DS18B2 dengan mengimplementasikan metode logika fuzzy berbasis mikrokontroler. Jadi diharapkan prototype monitoring suhu pada cool box ikan dapat mempermudah supplierikan untuk memonitoring kestabilan suhu cool box dengan menggunakan website.

\section{METODOLOGI PENELITIAN}

\subsection{Bahan dan Alat Penelitian}

Bahan atau objek yang digunakan pada penelitian ini berdasarkan hasil survei dan observasi di tempat, diantaranya: Es, Ikan, cool box. Sedangkan alat 
penelitian yang dipakai dalam penelitian ini berupa perangkat keras (hardware) seperti : Cool box, Modem Wireless, Kabel Jumper, Kabel USB, Komputer / laptop dengan spesifikasi minimal Dual Core dan RAM 2GB, dan Sensor suhu DS18B20. Sedangkan yang diperlukan dalam pembuatan sistem pada penelitian ini software adalah Bahasa Pemograman PHP, Arduino IDE, MySQLi sebagai database dan Web browser.

\subsection{Perancangan Sistem}

Untuk penelitian ini terdiri dari 2 tahapan perancangan sistem, yaitu membuat hardware untuk sebagai alat serta menginstal aplikasinya. Kemudian membuat system memonitor sebagai user interface yang berbasis website untuk menampilkan data yang sudah dikirim oleh perangkat keras lalu disimpan di database.

\subsection{Prosedur Penelitian}

Prosedur atau tahapan penelitian yang dilakukan pada penelitian ini memalui beberapa tahapan guna untuk memudahkan pelaksanaan penelitian dan juga sebagai pedoman dalam melaksanakan penelitian agar tercapainya tujuan penelitian, berikut tahap-tahap penelitian yang dilakukan,

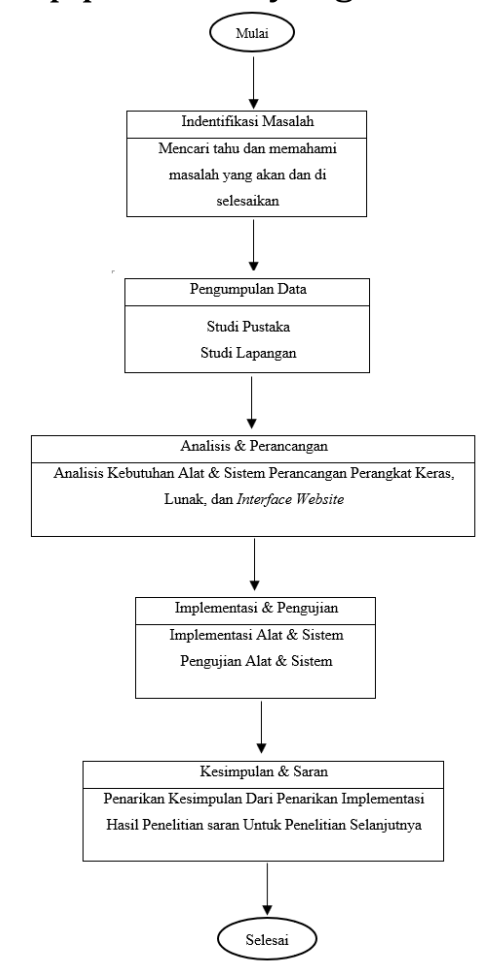

Gambar 3.1 Tahapan Penelitian

Terdapat beberapa tahapan prosedur penelitian yang digunakan, yaitu dimulai dengan mengidentifikasi masalah dengan cara memfokuskan, mencari tahu, memahami, dan mengetahui batasan-batasan masalah yang akan dilakukan penelitian. Kedua tahapan pengumpulan data yang dilakukan dengan cara 
melakukan studi pustaka dan studi lapangan. Ketiga tahapan analisis dan perancangan yang mana tertuju pada hardware dan software serta interface website yang diperlukan.

Keempat implementasi dan pengujian, pada tahapan ini akan dilakukan implementasi dan pengujian terhadap hardware dan software yang telah dibuat serta implementasi dan pengujian terhadap data yang didapat melalui uji coba hardware. Kelima yaitu tahapan terakhir dimana pada tahapan ini akan ditarik kesimpulan dari pembuatan hardware dan software yang telah dibuat serta pemberian saran untuk pengembangan penelitian selanjutnya.

\subsection{Gambaran Umum Sistem}

Gambaran umum sistem yang dibuat adalah monitoring suhu pada cool box ikan. Pada gambaran di bawah dijeslakan ada beberapa komponen yang dipakai nantinya dan saling berhubungan seperti mikrokontroler, led, sensor ds18b20, cool box, server, database, website dan juga HP.

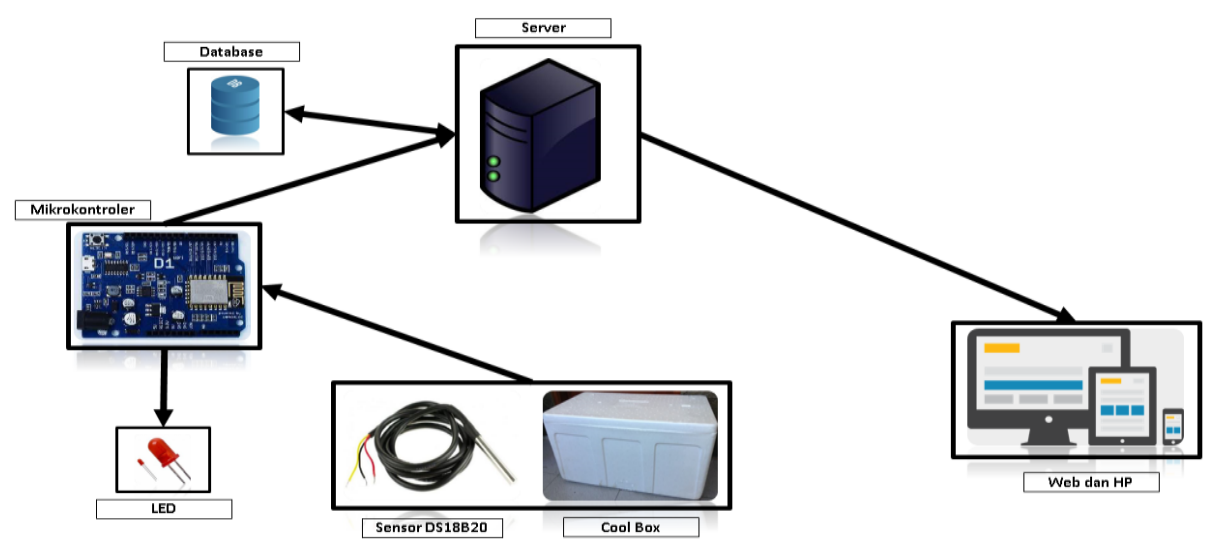

Gambar 1 Rancangan Umum Sistem

\section{HASIL DAN PEMBAHASAN}

Pada bagian ini diberikan hasil penelitian yang dilakukan sekaligus dibahas secara komprehensip. Hasil bisa berupa gambar, grafik, tabel dan lain-lain yang mempermudah pembaca paham dan diacu di naskah. Jika bahasan terlalu panjang dapat dibuat sub-sub judul, seperti contoh berikut.

\subsection{Pengolahan Data}

Secara garis besar, diagram blok proses inferensi fuzzy [22] dinyatakan sebagai berikut:

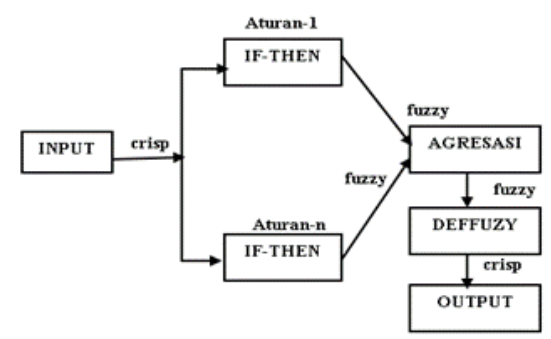

Gambar 1 Diagram blok sistem inferensi fuzzy 
Untuk mendapatkan output diperlukan 4 tahapan, diantaranya:
a.Pembentukan Himpunan Fuzzy
b. Aplikasi Fungsi Implikasi
c. Komposisi Aturan
d. Defuzzifikasi

Berikut adalah perhitungan manual memprediksi suhu didalam cool box, sesuai 4 langkah tersebut.

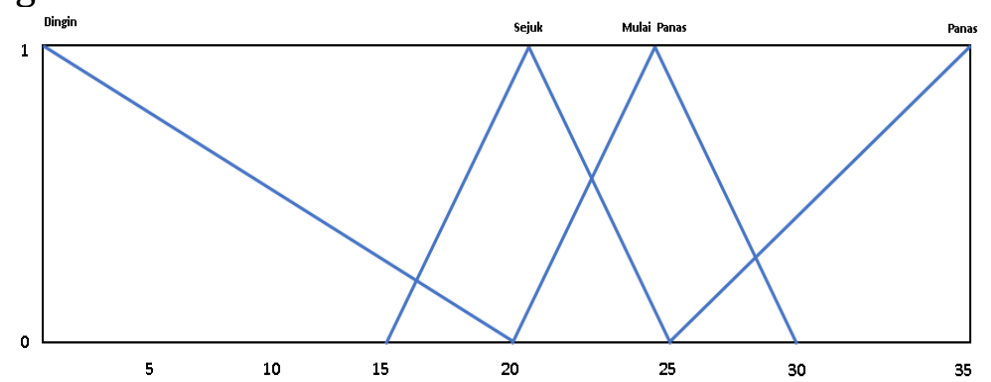

Gambar 2 Himpunan fuzzy untuk variabel input suhu

Derajat Keanggotaan $\mu[\mathrm{x}]$

$$
\begin{aligned}
& \mu[x] \text { Dingin }=\left\{\begin{array}{cc}
1 & , x \leq 0 \\
\frac{20-x}{20-0}, & 0 \leq x \leq 20 \\
0 & , x \geq 20
\end{array}\right. \\
& \mu[x] \text { Sejuk }= \begin{cases}0 & , x \geq 20 \\
\frac{x-15}{20-15} & , x \leq 15 \text { atau } x \geq 25 \\
\frac{25-x}{25-20} & , 15 \leq x \leq 20 \\
, 20 \leq x \leq 25\end{cases}
\end{aligned}
$$

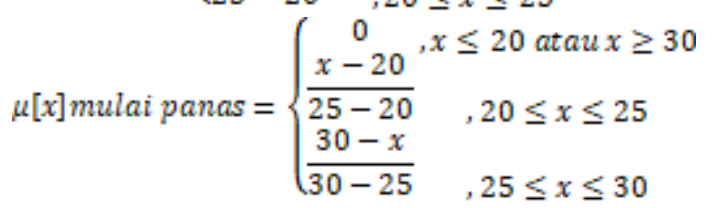

$$
\begin{aligned}
& \mu[x] \text { Panas }=\left\{\begin{array}{cc}
0 & { } x \leq 25 \\
\frac{x-25}{30-25}, & 25 \leq x \leq 30 \\
1 & , x \geq 30
\end{array}\right.
\end{aligned}
$$

Jika diketahui yang didapat misalkan suhu 16 maka :

(Suhu 16)

$$
\begin{aligned}
& \mu[x] \text { Dingin }=\frac{20-16}{20-0}=0,2 \\
& \mu[x] \text { Sejuk }=\frac{16-15}{20-15}=0,2 \\
& \mu[x] \text { Mulai Panas }=0 \\
& \mu[x] \text { Panas } \quad=0
\end{aligned}
$$




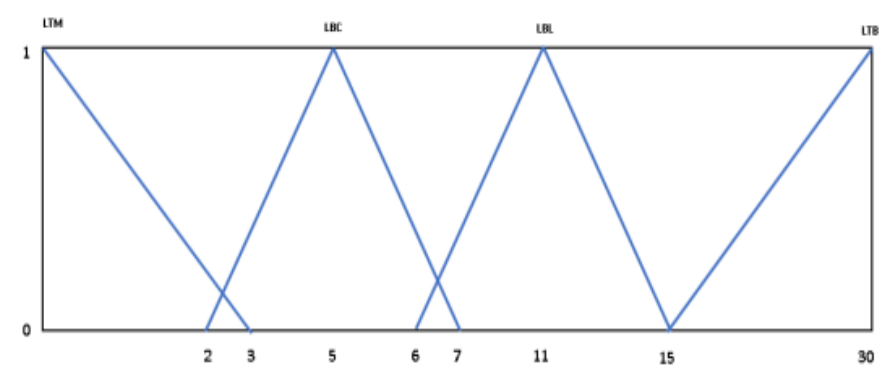

Gambar 3 Himpunan fuzzy untuk variabel output Lampu

Derajat Keanggotaan $\mu[\mathrm{y}]$ (dari Gambar 3)

$\mu[y] L T M= \begin{cases}\frac{1}{3-y} & , y \leq 0 \\ \frac{3-0}{0}, 0 \leq y \leq 3\end{cases}$
$\mu[y] L B C= \begin{cases}0, & , y \geq 3 \\ \frac{y-2}{5-2} & , 2 \leq \text { atau } y \geq 7 \\ \frac{7-y}{7-5} & , 5 \leq y \leq 5\end{cases}$
$\mu[y] L B L=\left\{\begin{array}{cc}0 & , y \leq 6 \text { atau } y \geq 15 \\ \frac{y-6}{11-6} & , 6 \leq y \leq 11 \\ \frac{15-y}{15-11} & , 11 \leq y \leq 15\end{array}\right.$
$\mu[y] L T B=\left\{\begin{array}{cc}0 & , y \leq 15 \\ \frac{y-15}{30-15}, & 15 \leq y \leq 30 \\ 1 & , y \geq 30\end{array}\right.$

Aplikasi fungsi implikasi (RULE)

[Rule1] IF Suhu Dingin THEN Lampu Tidak Menyala (LTM)

Predikat $=\mu$ Suhu Dingin $\cap \mu$ LampuTidak Menyala $($ LTM $)=0,2$

[Rule 2] IF Suhu Sejuk THEN Lampu Bekedip Cepat (LBC)

Predikat $=\mu$ Suhu Sejuk $\cap \mu$ Lampu Bekedip Cepat $(L B C)=0,2$

[Rule 3] IF Suhu Mulai Panass THEN Lampu Bekedip Lambat (LBL)

Predikat $=\mu$ Suhu Mulai Panas $\cap \mu$ Lampu Bekedip Lambat (LBL) $=0$

[Rule 4] IF Suhu Panas THEN Lampu Tidak Berkedip (LTB)

Predikat $=\mu$ Suhu Panas $\cap \mu$ Lampu Tidak Berkedip $(\mathrm{LBL})=0$

Inferensi RULE

Perhitungan inferensi menetukan nilai z1,z2, z3, z4, z5, dan z6 bawah dalam fungsi keanggotaan.

Jika Nilai NAIK zMIN - (a_predikat *(zMIN - zMAX))

Jika Nilai TURUN zMAX - (a_predikat*(zMAX - zMIN)) 


$$
\begin{aligned}
& \text { a_dingin }=0,2 \\
& \text { a_sejuk }=0,2 \\
& \text { a__mulai panas }=0 \\
& \text { a_panas =0 } \\
& \mathrm{z} 1=3-\left(0,2^{*}(3-0)\right) \\
&=3-\left(0,2^{*} 3\right) \\
&=3-0,6 \\
&=2,4 \\
& \mathrm{z} 2=2-\left(0,2^{*}(2-7)\right) \\
&=2-\left(0,2^{*}(-5)\right) \\
&=2-(-1) \\
&=3 \\
& \mathrm{z} 3=7-\left(0,2^{*}(7-2)\right) \\
&=7-\left(0,2^{*}(5)\right) \\
&=7-1 \\
&=6 \\
& \mathrm{z} 4=6-(0 *(6-15)) \\
&=6-(0 *(-9)) \\
&=6-0 \\
&=6 \\
& \mathrm{z} 5=15-(0 *(15-6)) \\
&=15-(0 *(9)) \\
&=15-0 \\
&=15 \\
& \mathrm{z} 6=15-(0 *(15-30)) \\
&=15-(0 *(-15)) \\
&=15-0 \\
&=15
\end{aligned}
$$

Defuzzyfikasi

$$
\begin{aligned}
& Z=\frac{\left(z 1 * a_{\text {predikat } 1}\right)}{a_{\text {praditis }}} \\
& z=\frac{\begin{array}{c}
a_{\text {predikat }} \\
(2,4 * 0,2\}+[3 * 0,2\}+0.6 * 0.2)+0.6 * 0\}+[15 * 0\}+[15 * 0)
\end{array}}{0.2+0.2+0.2+0+0+0} \\
& Z=\frac{0,48+0,6+1,2+0+0+0}{0,6} \\
& Z=\frac{2,28}{0,6} \\
& Z=3,8
\end{aligned}
$$

Jadi hasil yang didapat adalah 3,8 detik untuk waktu lampu akan menyala

\subsection{Implementasi Antar Muka Pada Sistem}

Berikut ini merupakan tampilan dari website yang berfungsi untuk menampilkan hasil kiriman data setelah setelah dihasilkan dan diolah oleh mikrokontroler wemos D1 sesuai dengan program yang sudah dibuat. 


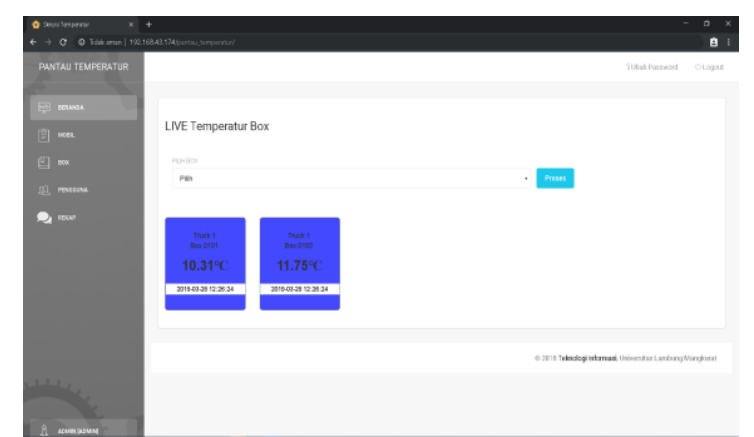

Gambar 4 Tampilan laman beranda website

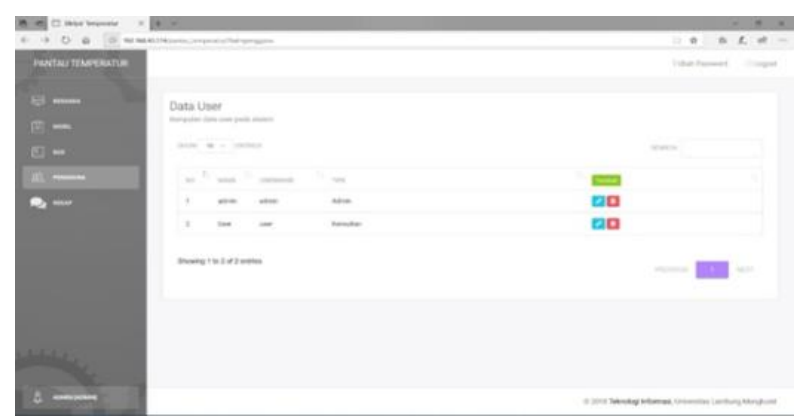

Gambar 5 Tampilan laman data user

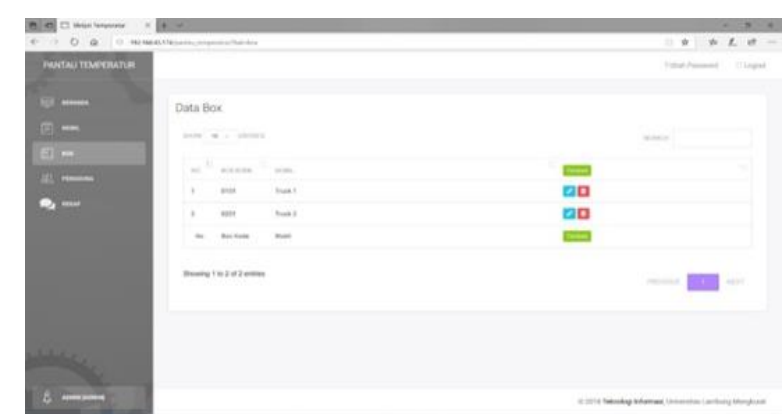

Gambar 6 Tampilan laman data cool box

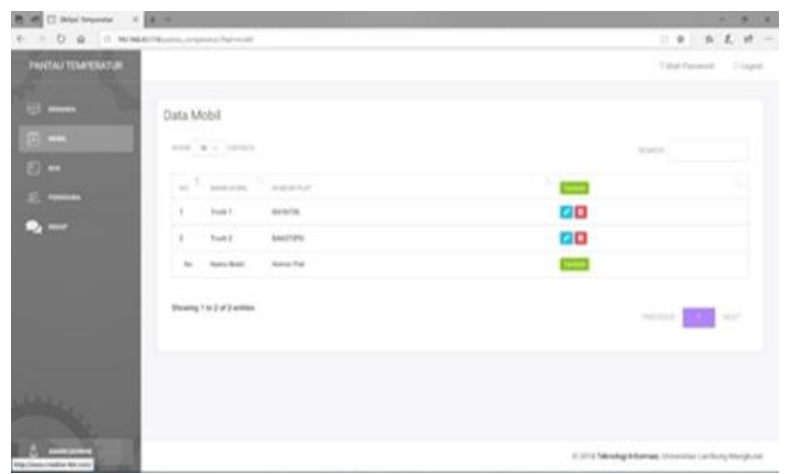

Gambar 7 Tampilan laman data kendaraan pembawa cool box 


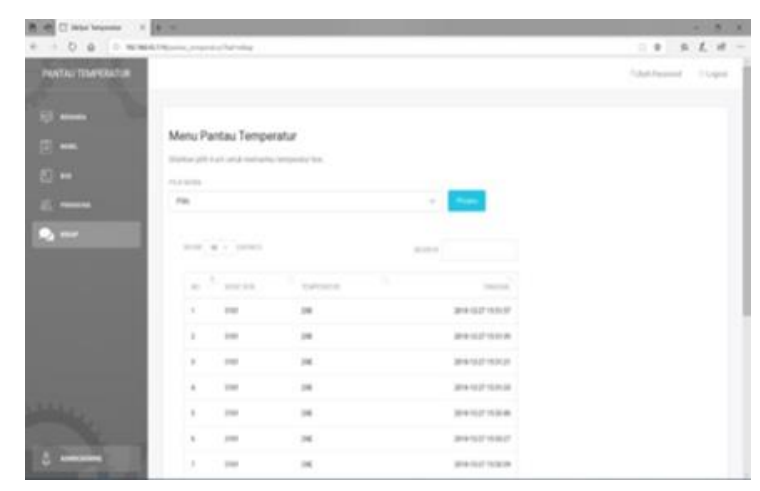

Gambar 8 Tampilan laman rekap data suhu

\subsection{Pengujian Sistem}

Pada bagian ini dilakukan pengujian terhadap sistem yang telah dibuat, yang tentunya sesuai dengan rumus yang ada pada bagian skenario pengujian. Ini adalah foto dari rangkaian wemos D1 yang digunakan dalam penelitian

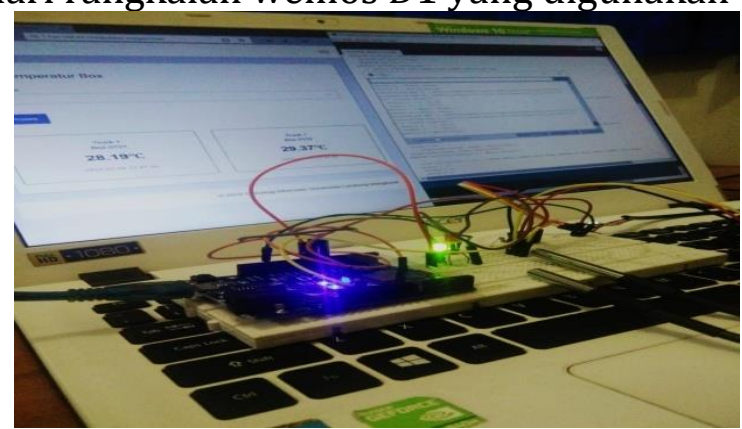

Gambar 9 Rangkaian wemos D1 monitoring suhu cool box

\subsection{Skenario Pengujian}

Untuk skenario pertama dilakukan pengujian menggunakan mobil untuk melakukan test atau percobaan secara langsung dengan menggunakan $2 \mathrm{cool}$ box yang setiap cool box-nya masing - masing berisikan 5 es batu bungkus yang bisa dibeli di toko maupun warung eceran lalu dihancurkan es tersebut dan 6 sampai 7 botol minuman yang terisi penuh sebelum berangkat.

Untuk skenario kedua penulis melakukan pengujian ditempat tidak bergerak. Sama seperti sebelumnya penulis menggunakan 2 cool box yang setiap cool box-nya masing - masing berisikan 5 es batu bungkus yang bisa dibeli ditoko maupun warung eceran lalu dihancurkan es tersebut dan 6 sampai 7 botol minuman yang terisi penuh sebelum menguji.

Pada penelitian ini digunakan metode logika fuzzy tsukamoto untuk mengetahui keakurasian suhu didalam cool box yang sudah di tentukan dalam sistem ini. Monitoring menggunakan parameter-parameter kendali logika fuzzy tsukamoto yang disusun dan diklasifikasikan berdasarkan pengujian karakteristik sistem dan pengukuran suhu didalam cool box yang sebenarnya agar penerapan monitoring suhu cool box dapat dioptimalkan. 
Pengujian akurasi sensor terhadap perubahan suhu, dilakukan dengan memonitoring perubahan suhu (bertambah dan berkurang). Adapun rumus yang digunakan untuk pengujian hasil sistem ini adalah sebagai berikut.

\section{TP}

$\mathrm{X} 100 \%=$

$$
\mathrm{TP}+\mathrm{FN}
$$

Keterangan:

- $\mathrm{TP}$ (true positive) = sering juga disebut hit rate, menunjukkan pengukuran yang benar.

- $\quad$ FN (false negative) = jumlah yang tidak terklasifikasi .

Suhu terakumulasi setelah 15 sampai 20 menit dan hasil pengujian setelahnya ditunjukkan pada Tabel 1 untuk monitoring di depan rumah dan Tabel 2 saat diperjalanan.

Tabel 1 Pengujian Akurasi Sensor DS18B20 di Mobil Yang Berjalan

\begin{tabular}{|c|c|c|c|c|c|c|}
\hline Waktu & Sensor & Sensor & Indikator & Indikator & Akurasi & Akurasi \\
\hline \multirow[t]{3}{*}{ Percobaan } & $\begin{array}{c}\text { Suhu } \\
\text { DS18B20 }\end{array}$ & $\begin{array}{c}\text { Suhu } \\
\text { DS18B20 }\end{array}$ & Lampu & Lampu & $\begin{array}{c}\text { Sensor } \\
\text { DS18B20 }\end{array}$ & $\begin{array}{c}\text { Sensor } \\
\text { DS18B20 }\end{array}$ \\
\hline & 1/ & $2 /$ & Sensor 1 & Sensor 2 & $\begin{array}{c}\text { (Sensor Suhu) } \\
1\end{array}$ & $\begin{array}{c}\text { (Sensor Suhu) } \\
2\end{array}$ \\
\hline & (2 menit) & (2 menit) & & & & \\
\hline 2Menit & 12.5 & 11 & Sesuai & Sesuai & $\mathrm{Ya}$ & $\mathrm{Ya}$ \\
\hline 4Menit & 12.19 & 10.81 & Sesuai & Sesuai & $\mathrm{Ya}$ & $\mathrm{Ya}$ \\
\hline 6Menit & 11.94 & 10.56 & Sesuai & Sesuai & $\mathrm{Ya}$ & $\mathrm{Ya}$ \\
\hline 8Menit & 11.69 & 10.31 & Sesuai & Sesuai & $\mathrm{Ya}$ & $\mathrm{Ya}$ \\
\hline 10 Menit & 11.38 & 10 & Sesuai & Sesuai & $\mathrm{Ya}$ & $\mathrm{Ya}$ \\
\hline 12 Menit & 11.12 & 9.75 & Sesuai & Sesuai & $\mathrm{Ya}$ & $\mathrm{Ya}$ \\
\hline 14Menit & 10.59 & 8.69 & Sesuai & Sesuai & $\mathrm{Ya}$ & $\mathrm{Ya}$ \\
\hline 16 Menit & 10.44 & 8.5 & Sesuai & Sesuai & $\mathrm{Ya}$ & $\mathrm{Ya}$ \\
\hline 18 Menit & 10.25 & 8.25 & Sesuai & Sesuai & $\mathrm{Ya}$ & $\mathrm{Ya}$ \\
\hline 20Menit & 9.75 & 7.85 & Sesuai & Sesuai & $\mathrm{Ya}$ & $\mathrm{Ya}$ \\
\hline 22 Menit & 9.63 & 7.75 & Sesuai & Sesuai & Ya & $\mathrm{Ya}$ \\
\hline Akurasi & & & $100 \%$ & $100 \%$ & $100 \%$ & $100 \%$ \\
\hline
\end{tabular}

Tabel 2 Pengujian Akurasi Sensor DS18B20 di Tempat Diam

\begin{tabular}{|c|c|c|c|c|c|c|c|c|}
\hline Waktu & Sensor & Sensor & Pengukur & Pengukur & Indikator & Indikator & Akurasi & Akurasi \\
\hline Percobaan & $\begin{array}{c}\text { Suhu } \\
\text { DS18B20 }\end{array}$ & $\begin{array}{c}\text { Suhu } \\
\text { DS18B20 }\end{array}$ & $\begin{array}{c}\text { Suhu } \\
\text { Manual }\end{array}$ & $\begin{array}{c}\text { Suhu } \\
\text { Manual }\end{array}$ & Lampu & Lampu & $\begin{array}{c}\text { Sensor } \\
\text { DS18B20 }\end{array}$ & $\begin{array}{c}\text { Sensor } \\
\text { DS18B20 }\end{array}$ \\
\hline & 1/ & 2/ & $\begin{array}{c}\text { Dalam } \\
\text { Cool Box } \\
1 /\end{array}$ & $\begin{array}{c}\text { Dalam } \\
\text { Cool Box } \\
2\end{array}$ & Sensor 1 & Sensor 2 & $\begin{array}{l}\text { (Sensor } \\
\text { Suhu) } 1\end{array}$ & $\begin{array}{l}\text { (Sensor } \\
\text { Suhu) } 2\end{array}$ \\
\hline & (5 menit) & (5 menit) & (5 menit) & (5 menit) & & & & \\
\hline 5 Menit & 9.2 & 9.12 & 9 & 9 & Sesuai & Sesuai & $\mathrm{Ya}$ & $\mathrm{Ya}$ \\
\hline 10Menit & 9.7 & 9.14 & 9 & 9 & Sesuai & Sesuai & $\mathrm{Ya}$ & $\mathrm{Ya}$ \\
\hline 15 Menit & 9.9 & 9.21 & 9 & 9 & Sesuai & Sesuai & $\mathrm{Ya}$ & $\mathrm{Ya}$ \\
\hline 20Menit & 9.12 & 9.25 & 9 & 9 & Sesuai & Sesuai & $\mathrm{Ya}$ & $\mathrm{Ya}$ \\
\hline 25 Menit & 9.12 & 9.23 & 9 & 9 & Sesuai & Sesuai & $\mathrm{Ya}$ & Ya \\
\hline 30Menit & 9.14 & 9.28 & 9 & 9 & Sesuai & Sesuai & $\mathrm{Ya}$ & $\mathrm{Ya}$ \\
\hline 35 Menit & 9.12 & 9.22 & 9 & 9 & Sesuai & Sesuai & $\mathrm{Ya}$ & Ya \\
\hline 40 Menit & 9.22 & 9.22 & 9 & 9 & Sesuai & Sesuai & $\mathrm{Ya}$ & Ya \\
\hline 45 Menit & 9.25 & 9.28 & 9 & 9 & Sesuai & Sesuai & $\mathrm{Ya}$ & $\mathrm{Ya}$ \\
\hline 50Menit & 9.27 & 9.34 & 9 & 9 & Sesuai & Sesuai & $\mathrm{Ya}$ & $\mathrm{Ya}$ \\
\hline 55 Menit & 9.10 & 9.37 & 9 & 9 & Sesuai & Sesuai & $\mathrm{Ya}$ & $\mathrm{Ya}$ \\
\hline 60 Menit & 9.31 & 9.42 & 9 & 9 & Sesuai & Sesuai & $\mathrm{Ya}$ & $\mathrm{Ya}$ \\
\hline 65 Menit & 9.36 & 9.47 & 9 & 9 & Sesuai & Sesuai & $\mathrm{Ya}$ & $\mathrm{Ya}$ \\
\hline 70 Menit & 9.44 & 85.00 & 9 & 9 & Sesuai & Tidak & $\mathrm{Ya}$ & Tidak \\
\hline 75 Menit & 85.00 & 10.44 & 9 & 9 & Tidak & Tidak & Tidak & Tidak \\
\hline 80 Menit & 9.13 & 9.48 & 9 & 9 & Sesuai & Sesuai & $\mathrm{Ya}$ & $\mathrm{Ya}$ \\
\hline 85 Menit & 9.24 & 9.55 & 9 & 9 & Sesuai & Sesuai & Ya & $\mathrm{Ya}$ \\
\hline Akurasi & & & & & $94.11 \%$ & $88.23 \%$ & $94.11 \%$ & $88.23 \%$ \\
\hline
\end{tabular}

Hasil pengujian skenario satu didapatkan tingkat akurasi indikator lampu juga akurasi sensor DS18B20 sebesar 100\% untuk sensor 1 dan sensor 2 . Hasil indikator lampu dan akurasi sensor DS18B20 sudah sesusai dengan output fuzzy yang dirancang. Hal itu terlihat dari suhu cool box yang dibaca sensor DS18B20 dan pengukur suhu manual mengeluarkan nilai yang hampir sama itu akan dikatakan sesuai. Lalu jika dari sensor DS18B20 tidak membaca suhu didalam cool box karena error atau semacamnya itu akan dikatakan tidak. Salah satu contoh error mengeluarkan nilai 85.00 atau -127 karena nilai maksimal yang dibaca sensor adalah antara 85 sampai -127 dan 
itu dikatakan tidak sesuai. Untuk skenario kedua akurasi indikator lampu dan akurasi sensor DS18B20 didapatkan sebesar sensor $194.11 \%$ dan sensor 2 sebesar $88.23 \%$ karena untuk pengujian dirumah peneliti sering membuka tutup cool box mengambil pengukur suhu ruangan untuk perbandingan sehingga ada beberapa error dalam pengambilan data. Akan tetapi hasil indikator lampu sudah tepat dan akurasi sensor DS18B20 sudah sesusai dengan output fuzzy yang dirancang.

\section{SIMPULAN}

Berdasarkan penelitian yang dilakukan dapat disimpulkan sebagai berikut:

a. Penggabungan antara mikrokontroler wemos D1 dengan sensor DS18B20 yang diaplikasikan pada website berhasil dilakukan dengan diketahui bekerjanya alat yang sudah dibuat menggunakan bahasa pemrograman $\mathrm{C}$.

b. Prototype monitoring suhu didalam cool box menggunakan metode logika fuzzy yang notifikasinya dikirim ke lampu LED dan ke website setelah dilakukan pengujian data dan mendapatkan nilai akurasi suhu yang tinggi.

c. Dengan pengiriman laporan yang real time, sistem monitoring ini dapat diimplementasikan untuk membantu supplier dalam mengecek dan memonitor suhu cool box secara lebih praktis tanpa harus membuka box dan mengecek secara manual. 


\section{DAFTAR PUSTAKA}

[1] E. Susanto dan A. Fahmi, “Senyawa Fungsional Dari Ikan: Aplikasi Dalam Pangan”, Jurnal Aplikasi Teknologi Pangan, vol. 1, pp. 95-102.

[2] N. Suryani, Rosita dan U. Hasanah, "Perbedaan Kadar Protein dan Kadar Lemak Ikan Patin (Pangasius hypophtalmus) yang Diolah secara Digoreng, Dipanggang dan Direbus", Jurnal Kesehatan Indonesia, pp. 3945, 2016.

[3] A. Apriyono, "Prosedur Penetapan Harga Jual”, 2007. [Online]. [Diakses Minggu Juli 2018].

[4] D. P. Budi, "Perancangan Prototype Alat Untuk Sistem Pemantauan Suhu dan Kelembaban Menggunakan Arduino Platform", repository.uksw, 2013.

[5] D. H. J. S. dan D. B. , “Pemantauan Suhu Dengan Mikrokontroler ATMEGA8 Pada jaringan Lokal”, Sekolah Tinggi Teknologi Nuklir.

[6] Y. A. Kumia, "Perbandingan Kualitas Antar Sensor Suhu dengan Menggunakan Arduino Pro mini”, Universitas Wijaya Kartika Surabaya, 2016.

[7] E. N. M. R. dan A. R. , “Rancang Bangun Termometer Digital Berbasis Sensor DS18B20 Untuk Penyandang Tunanetra", Universitas Telkom, vol. 4, p. 3, 2017.

[8] M. A. Bahruddin, “Rancang Bangun Alat Pengukuran Suhu Ruangan Berbasis Fuzzy Logic dan Jaringan TCP/IP", Universitas Islam Negeri.

[9] N. C. Basjaruddin, Pembelajaran Mekatronika Berbasis Proyek, c. u. utama, Penyunt., Yogyakarta, 2015.

[10] M. dan E. Istiyono, Fisika 1, Jakarta: Yudhistira, 2007.

[11] F. Supegina dan E. J. Setiawan, “Rancang Bangun IOT Temperature Controller Untuk Enclosure BTS Berbasis Microcontroller Wemos Dan Android", Jurnal Elektro, vol. VIII, pp. 145-150, 2 Mei 2017.

[12] Triyanto, "Media Pembelajaran Sensor Pir Parallax, Hall Effect, dan Sensor Ds18b20 Pada Mata Pembelajaran Sensor dan Aktuator di Smk Muhammadiyah Prambanan", pp. 23-24, 2016.

[13] Indotrading, www.indotrading.com, 2018. [Online]. [Diakses Selasa Juli 2018].

[14] R. Hidayat, Cara Praktis Membangun Website Gratis, Jakarta: Elex Media Komputindo, 2010.

[15] B. S. V. A. Suoth dan H. S. Kolibu, "Fuzzy, Rancang Bangun Sistem Kontrol Suhu Dan Ketinggian Air Untuk Pemijahan Ikan Dengan Menggunakan Logika", UNSRAT Manado, Manado, 2015.

[16] S. Kusumadewi, “Aplikasi Logika Fuzzy Untuk Pendukung Keputusan”, Graha Ilmu, Yogyakarta, 2013. 
[17] P. Mandarani, “Perancangan Dan Implementasi User Interfae Berbasis Web Untuk Monitoring Suhu, Kelembaban Dan Asap Pada Ruangan Berbeda Dengan Memanfaatkan Jaringan Local Area Network", Jurnal Teknik Informatika, pp. 37-42, 2014.

[18] R. Candra, "Alat Pemantau Suhu Ruangan Melalui Web Berbasis Mikrokontroler AT89S51", Jurnal Sistem Komputer, pp. 534-538, 2006.

[19] T. D. Madyanto, I. Santoso dan I. Setiawan, "Pengontrolan Suhu Menggunakan Metode Fuzzy -PID", Universitas Diponegoro Semarang, Semarang, 2010.

[20] D. Prihatmoko, "Perancangan Dan Implementasi Pengontrol Suhu Ruangan Berbasis Mikrokontroler Arduino Uno", Jurnal Simetris, pp. 117-122, 2016.

[21] D. Erlina, "Sistem Pengendali Lampu Ruangan Secara Otomatis Menggunakan Pc Berbasis Mikrokontroler Arduino UNO", Jurnal Teknik Informatika, pp. 1-6, 2013.

[22] S. Kusumadewi, "Aplikasi Logika Fuzzy untuk Pendukung Keputusan", Graha Ilmu, Yogyakarta, 2013.

[23] S. Bandong, H. S. Kolibu dan V. A. Suoth, "Rancang Bangun Sistem Kontrol Suhu Dan Ketinggian Air Untuk Pemijahan Ikan Dengan Menggunakan Logika Fuzzy", UNSRAT Manado, Manado, 2015. 